2. Stor underrapportering av skader i Norge. 25.11.2016 https://www.dagensmedisin. no/artikler/2016/11/25/-stor-underrapportering-av-skader-i-norge/ (18.4.2017).

3. Helsedirektoratet. Personskadedata 2015. 05/2016 Oslo: Helsedirektoratet, 2016. https://helsedirektoratet no/Lists/Publikasjoner/Attachments/1189/ Personskader\%202015.pdf (18.4.2017).

4. Myklestad I, Alver K, Madsen C et al. Skadebildet i Norge. Hovedvekt på personskader i sentrale registre. 2/2014. Oslo: Folkehelseinstituttet, 2014.

\section{Re: Glemsk og glemt}

Tor Rosness tar opp viktige problemstillinger (1). Fremdeles stilles demensdiagnosen i mange tilfeller sent, slik at både medikamentelle og ikke minst ikke-medikamentelle tiltak kommer sent i gang. $\AA$ hevde at «en kurativ behandling for øyeblikket er uoppnåelig», virker derimot vel pessimistisk. Det er i dag en rekke studier med antistoff rettet mot amyloid under utprøving (2). Utfordringen til nå har vært å komme tidlig nok til med behandling før sykdommen har fătt utviklet seg for mye. Pasientene som til nå er blitt inkludert i legemiddelutprøvingene, har hatt mild til moderat demens. I USA har det ikke vært rutine å gjøre spinalpunksjon for måling av demensmarkører eller PET-skanning for amyloid («amyloid-PET») før inklusjon i legemiddelutprøvinger, som for eksempel i utprøvingen av bapineuzumab hvor en i $25 \%$ av tilfellene ved hjelp av PET ikke kunne påvise amyloid i hjernen til pasientene som var inkludert (3). De ulike antistoffene er biologisk forskjellige og har også ulike virkningsmekanismer slik at effekten av behandlingen er ulik (2). Dette er medvirkende årsaker til at utprøvingene hittil har mislyktes.

Inklusjonskriteriene for de neste utprøvingene er nå endret slik at pasientene må ha påvist amyloid i hjernen for å kunne inkluderes. Yngre pasienter i en tidligere sykdomsfase tillates inkludert. På Oslo universitetssykehus og Akershus universitetssykehus vil vi i løpet av året starte inklusjon til to av antistoffutprøvingene det knyttes store forventninger til $(4,5)$. Majoriteten av våre demenspasienter vil dessverre ikke kunne nyttiggjøre seg denne behandlingen både på grunn av sykdommen er for langt kommet, men også fordi mange pasienter (spesielt de eldste) etiologisk sett har blandingsdemenser. Hos de som er aktuelle for slik behandling, og det gjelder ikke minst de yngste Alzheimer-pasientene, er det derimot viktig å stille diagnosen tidlig. Derfor vil forskning på tidlig diagnostikk av Alzheimers demens være av stor betydning i tiden fremover. På Hukommelsesklinikken på Ullevål skal vi nå igangsette avansert forskning på nye metoder for tidlig diagnostikk. Håpet er at flere vil kunne nyttiggjøre seg behandlingen som nå er under utvikling.

\section{Anne-Brita Knapskog}

anne-brita@knapskog.net

Nenad Bogdanovic
Anne-Brita Knapskog er overlege og postdoktor ved Hukommelsesklinikken, Geriatrisk avdeling, Oslo universitetssykehus.

Ingen oppgitte interessekonflikter.

Nenad Bogdanovic er professor ved Geriatrisk avdeling, Universitetet i Oslo og overlege ved Karolinska Institutet i Stockholm.

Ingen oppgitte interessekonflikter.

Litteratur

1. Rosness TA. Glemsk og glemt. Tidsskr Nor Legeforen 2017; 137: 339.

2. Scheltens P, Blennow K, Breteler MM et al. Alzheimer's disease. Lancet 2016; 388: 505-17.

3. Vandenberghe R, Rinne JO, Boada M et al; Bapineuzumab 3000 and 3001 Clinical Study Investigators. Bapineuzumab for mild to moderate Alzheimer's disease in two global, randomized, phase 3 trials. Alzheimers Res Ther 2016; 8: 18.

4. Sevigny J, Chiao P, Bussière $T$ et al. The antibody aducanumab reduces $A \beta$ plaques in Alzheimer's disease. Nature 2016; 537: 50-6.

5. Ultsch M, Li B, Maurer T et al. Structure of Crenezumab Complex with A $\beta$ Shows Loss of $\beta$-Hairpin. Sci Rep 2016; 6: 39374.

Arild Bjørndal har sendt inn en kommentar til Erlend Hems artikkel om riktig skrivemåte for sykehusnavn i Tidsskriftet nr. 5/2017. Bjørndal spør om Helse Sør-Øst er riktig skrivemåte.

\section{E. Hem svarer:}

Skrivemåten Helse Sør-Øst er ikke i tråd med rettskrivningsreglene (1). Jeg vet ikke hvorfor helseforetaket har valgt denne skrivemåten, og det kunne jo være interessant å spørre dem om grunnen. Problemstillingen gjelder også andre helseforetak: Både Helse Vest og Helse Nord har valgt skrivemåter som avviker fra rettskrivningsreglene. Helse Midt-Norge er uproblematisk siden Midt-Norge er en landsdel og dermed et egennavn.

Det er faktisk mulig å få til dette riktig. Skatteetaten bruker Skatt øst, Skatt sør, Skatt vest, Skatt Midt-Norge og Skatt nord for regioninndelingene i organisasjonen (2). Det samme gjør Bufetat med benevnelsene Bufetat, region sør, Bufetat, region øst osv (3).

\section{Erlend Hem}

erlend.hem@medisin.uio.no

Erlend Hem er redaktør for språkspalten i Tidsskriftet. Ingen oppgitte interessekonflikter.

\section{Litteratur}

1. Stor og liten forbokstav. Statsspråk 2015, nr. 3, side 3 . http://www.sprakradet.no/Vi-og-vart/Publikasjoner/Statssprak/ statssprak-32015/stor-og-liten-forbokstav (27.4.2017).

2. Organisasjonen. Om Skatteetaten. http://www.skatteetaten.no/no/ Om-skatteetaten/Om-oss/Organisasjon-og-ledelse/Organisasjonen (27.4.2017).

3. Bufetats regionkontorer. https://www.bufdir.no/Kontakt/Bufetat_regionkontorer/ (27.4.2017). 